\title{
Hubungan Tingkat Pengungkapan dan Kinerja Corporate Social Responsibility Serta Manajemen Laba: Pengujian Teori Ekonomi dan Sosio-Politis
}

\author{
Dwi Ratmono ${ }^{*}$, Agus Purwanto ${ }^{1}$, Nur Cahyonowati ${ }^{1}$ \\ ${ }_{1}^{1}$ Fakultas Ekonomika dan Bisnis, Universitas Diponegoro \\ Gedung Widya Puraya Sayap Timur, Jl. Prof. Sudharto, SH., Tembalang, Semarang 50275 \\ *Penulis korespondensi; email: dwi_ratmono@yahoo.com
}

\begin{abstract}
ABSTRAK
Tujuan dari penelitian ini adalah menguji secara empiris hubungan antara tingkat kinerja corporate social responsibility (CSR), tingkat pengungkapan CSR, dan manajemen laba. Dengan menggunakan teknik purposive sampling, diperoleh sampel sebanyak 143 pengamatan yang menjadi peserta PROPER untuk periode amatan 2009-2013. Pengujian hipotesis menggunakan analisis SEM Partial Least Squares (PLS). Hasil penelitian menunjukkan temuan yang konsisten bahwa tingkat kinerja CSR berpengaruh positif terhadap tingkat pengungkapan CSR. Temuan ini mengindikasikan dukungan terhadap teori berbasis ekonomi khususnya teori signaling. Hasil penelitian juga menunjukkan kecenderungan bahwa perusahaan yang mempunyai tingkat pengungkapan CSR yang tinggi cenderung melakukan praktek manajamen laba yang rendah. Tidak ditemukan bukti empiris hubungan antara tingkat kinerja CSR dan manajemen laba.
\end{abstract}

Kata kunci: Kinerja CSR, pengungkapan CSR, manajemen laba.

\begin{abstract}
The objective of this research is to examine the relationship among corporate social responsibility (CSR) performance, CSR disclosure, and earnings management. Using purposive sampling technique, this research obtain 143 observation as research sample which are PROPER participants for 2009-2013 observations period. Hypotheses testing was conducted using SEM Partial Least Squares (PLS). The results of this research show consistent findings that CSR performance affects positively CSR disclosure. This finding indicate a support for economic-based theory especially signalling theory. The result also shows that companies that have higher level of CSR disclosure tend to have lower practice of earnings management. There is no an empirical evidence for relationship between CSR performance and earnings management.
\end{abstract}

Keywords: CSR performance, CSR disclosure, earnings management.

\section{PENDAHULUAN}

Tanggung jawab sosial dan lingkungan korporasi (corporate social responsibility, selanjutnya disingkat CSR) saat ini menjadi isu penelitian yang menarik karena para pemangku kepentingan (stakeholders) menuntut transparansi dampak dari aktivitas bisnis perusahaan (Kim et al., 2012).
Keprihatinan terhadap semakin memburuknya kondisi lingkungan dan sosial akibat aktivitas bisnis perusahaan-perusahaan juga telah menjadi permasalahan dunia pada saat ini (Moser dan Martin, 2012). Data Global Trend Graphs menunjukkan adanya ancaman karena kerusakan lingkungan bagi kelangsungan kehidupan generasi mendatang (Gambar 1). 


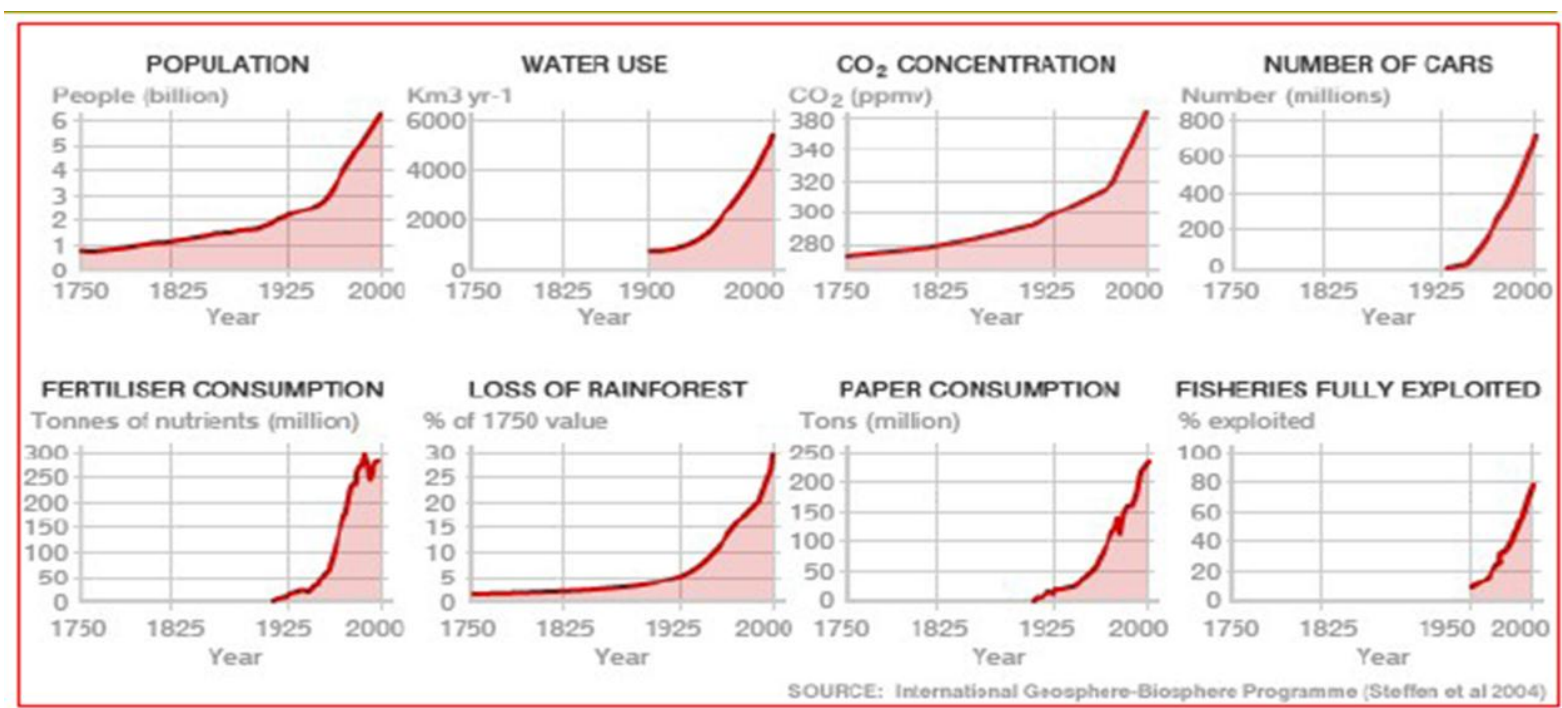

Sumber: Global Trend Graphs dari Website BBC, "Planet under Pressure”, 2004

\section{Gambar 1. Tren Global Kerusakan Lingkungan}

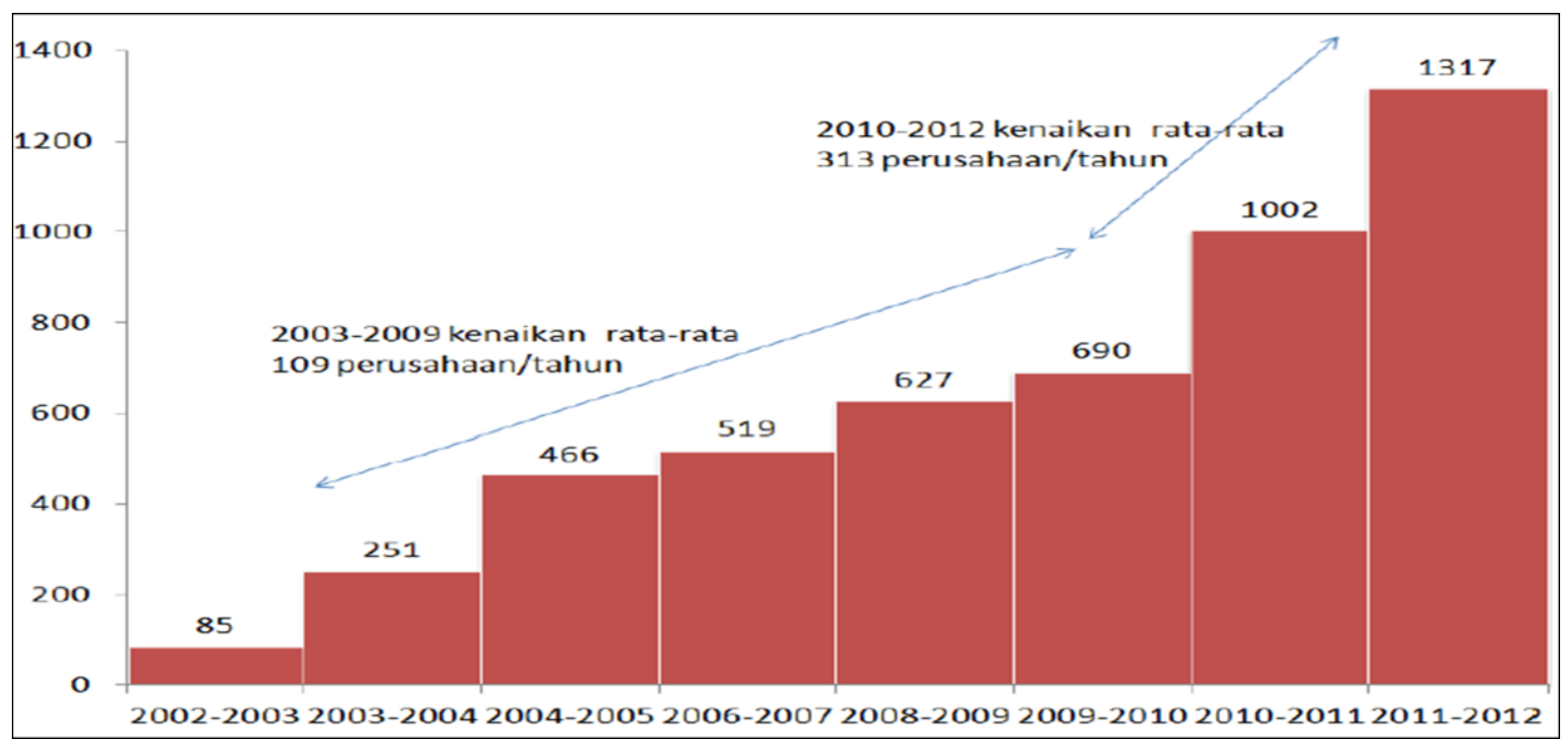

Gambar 2. Jumlah Perusahaan Peserta PROPER

Pemerintah Indonesia telah mendorong tanggung jawab sosial dan lingkungan (TJSL) ${ }^{1}$ perusahaan melalui Program Penilaian Peringkat Kinerja Perusahaan dalam Pengelolaan Lingkungan Hidup (PROPER) sebagai instrumen kebijakan yang dikeluarkan oleh Kementerian Negara

\footnotetext{
${ }^{1}$ Istilah Tanggung Jawab Sosial dan Lingkungan (TJSL) terdapat dalam Pasal 74 Undang-undang Nomor 40 tahun 2007 tentang Perseroan Terbatas dan Peraturan Pemerintah Nomor 47 Tahun 2012 tentang Tanggung Jawab Sosial dan Lingkungan Perseroan Terbatas. Istilah TJSL ini sama maknanya dengan konsep Corporate Social Responsibility (CSR) sehingga akan digunakan secara bergantian dalam penelitian ini.
}

Lingkungan Hidup. PROPER merupakan pengawasan pemerintah terhadap upaya perusahaan dalam melaksanakan ketentuan-ketentuan yang tercantum dalam peraturan perundang-undangan bidang lingkungan hidup yang berlaku. Berdasar teori berbasis ekonomi dan sosio-politis, banyak perusahaan berkeinginan membuat kesan (image) yang baik tentang kinerja CSR-nya (Clarkson et al.., 2008; Moser dan Martin, 2012). Oleh karena itu, tidak mengherankan jika jumlah perusahaan yang secara sukarela menjadi peserta PROPER terus bertambah sehingga menjadi 1.317 perusahaan pada tahun 2012 seperti grafik berikut pada Gambar 2. 
Pemerintah Indonesia memberikan perhatian pada isu CSR dengan menerbitkan Undangundang (UU) Nomor 40 tahun 2007 tentang Perseroan Terbatas. Pasal 74 UU tersebut mengamanatkan perusahaan-perusahaan yang menggunakan sumber daya alam untuk melaporkan aktivitas-aktivitas TJSL-nya. Dalam rangka pelaksanaan UU Nomor 40 tahun 2007 telah diterbitkan Peraturan Pemerintah (PP) Nomor 47 Tahun 2012 tentang Tanggung Jawab Sosial dan Lingkungan Perseroan Terbatas. Dalam PP ini diatur mengenai tanggung jawab sosial dan lingkungan yang bertujuan mewujudkan pembangunan ekonomi berkelanjutan guna meningkatkan kualitas kehidupan dan lingkungan yang bermanfaat bagi komunitas setempat dan masyarakat pada umumnya maupun Perseroan itu sendiri.

Isu utama yang belum terpecahkan dalam penelitian akuntansi sosial dan lingkungan adalah hubungan antara tingkat pengungkapan dan tingkat kinerja CSR perusahaan tersebut (Clarkson et al.., 2012; Kim et al.., 2012). Hasilhasil penelitian sebelumnya yang menguji hubungan dua variabel tersebut masih belum konsisten. Selain itu, terdapat isu lain yaitu apakah perusahaan yang mempunyai kinerja CSR yang baik juga akan berperilaku etis dengan tidak melakukan manipulasi atau manajemen laba (earnings management). Kim et al.. (2012) menyatakan hubungan antara pelaporan dan kinerja CSR serta manajemen laba menjadi menjadi pertanyaan penelitian yang penting karena ketidakkonsistenan hasil penelitian sebelumnya.

Kim et al.. (2012) menyatakan bahwa ketidakkonsistenan hasil penelitian CSR terdahulu karena adanya dua teori yang bertentangan (competing theories) yang memberikan prediksi yang berbeda tentang arah hubungan antara tingkat pelaporan CSR, tingkat kinerja CSR, dan manajemen laba. Dua teori yang bertentangan tersebut adalah teori berbasis ekonomis (economicbased theory) dan teori berbasis sosial-politis (sociopolitical theory). Hasil penelitian Clarkson et al.. (2008) menunjukkan bahwa teori berbasis ekonomis yang dapat menjelaskan hubungan antara tingkat pelaporan CSR dan tingkat kinerja CSR. Hasil penelitian Kim et al.. (2012) menunjukkan dukungan empiris terhadap teori sosio-politis. Namun dalam konteks Indonesia, masih menjadi pertanyaan penelitian tentang generalisasi temuan penelitian terdahulu tersebut. Hal ini karena kondisi sosial, politis, budaya, dan ekonomi serta faktor regulasi CSR yang berbeda. Perbedaan konteks institusional yaitu Indonesia termasuk kluster negara-negara code law dengan tingkat perlindungan investor yang lemah mungkin mem- batasi generalisasi temuan penelitian CSR dan manajemen laba terdahulu ke dalam konteks Indonesia (Leuz et al., 2003; Djankov, 2008). Isu ini penting diangkat mengingat penelitian-penelitian CSR di Indonesia baru mengangkat isu faktorfaktor yang mempengaruhi tingkat pengungkapan CSR (misalnya Suratno, 2006; Anggraini, 2006).

Masalah dampak negatif aktivitas bisnis perusahaan terhadap kondisi sosial dan lingkungan telah menjadi isu penting penelitian akuntansi (Moser dan Martin, 2012). Namun terdapat berbagai competing theories tentang hubungan tingkat pengungkapan CSR, kinerja CSR, dan manajemen laba (Hong dan Andersen, 2011; Kim et al., 2012). Selain itu, penelitian sebelumnya belum menggunakan desain penelitian yang memadai untuk menguji hubungan tingkat pengungkapan CSR, kinerja CSR, dan manajemen laba (Clarkson et al.., 2008). Bagaimana praktik CSR perusahaan-perusahaan di Indonesia setelah diterbitkannya UU No. 40 tahun 2007 dan PP No. 47 tahun 2012 masih menjadi pertanyaan penelitian yang penting.

Tujuan penelitian ini adalah sebagai menguji secara empiris hubungan simultan antara tingkat pengungkapan CSR, tingkat kinerja CSR, dan manajemen laba. Hasil penelitian ini diharapkan dapat menjadi bukti empiris teori yang relevan dalam menjelaskan praktek CSR di Indonesia karena adanya dua competing theories yang mempunyai hipotesis yang berbeda. Penelitian ini juga berkontribusi pada literatur akuntansi karena temuan penelitian terdahulu masih belum konsisten dalam menjelaskan hubungan tingkat pengungkapan CSR, kinerja CSR, dan manajemen laba (Chih et al.. 2008; Hong dan Andersen, 2011; Kim et al.., 2012). Penelitian ini diharapkan dapat berkontribusi dalam menjelaskan ketidakkonsistenan tersebut dengan menggunakan berbagai perspektif teori dalam menjelaskan hubungan ketiga variabel tersebut. Sesuai saran Moser dan Martin (2012), peneliti akuntansi harus menggunakan perspektif yang lebih luas dalam menjelaskan fenomena praktek CSR dan manajemen laba.

Penelitian ini juga berkontribusi untuk menjelaskan berbagai pelanggaran etika bisnis dengan menggunakan aktivitas CSR sebagai kedok penutup (Chih et al.., 2008; Hong dan Andersen, 2011). Sebagai contoh, perusahaan Enron yang melakukan skandal manipulasi laba terbesar dalam sejarah Amerika Serikat pada tahun 2000 ternyata melakukan aktivitas CSR secara intensif (Kim et al.., 2012). Bukti ini mengindikasikan penggunaan CSR sebagai sarana untuk menipu atau menyesatkan pemangku kepentingan dari aktivitas pelanggaran etika bisnis perusahaan. 
Dalam kasus Indonesia, masih belum ada penelitian yang menguji apakah aktivitas CSR digunakan untuk menutupi kecurangan manipulasi laba. Penelitian ini diharapkan berkontribusi untuk memberikan bukti empiris tersebut sehingga dapat menjadi sumber informasi bagi stakeholders dalam mengevaluasi kinerja CSR perusahaan. Perbedaan konteks institusional yaitu Indonesia termasuk kluster negara-negara code law dengan tingkat perlindungan investor yang lemah mungkin membatasi generalisasi temuan penelitian CSR dan manajemen laba terdahulu ke dalam konteks Indonesia (Leuz et al.., 2003; Djankov, 2008).

Meskipun terdapat berbagai definisi CSR, namun definisi yang ditawarkan oleh Caroll (1979) merupakan definisi yang paling banyak diterima. Ia menyatakan bahwa tanggung jawab sosial aktivitas bisnis meliputi ekspektasi ekonomi, hukum, etis, dan diskresionari yang dimiliki masyarakat terhadap perusahaan tersebut pada satu titik waktu. Caroll (1979) menyatakan bahwa perusahaan yang mempunyai tanggung jawab sosial yang baik harus berusaha untuk memperoleh laba, mematuhi hukum, berperilaku etis, dan menjadi warga negara yang baik dengan memberikan dukungan finansial pada aktivitas sosial.

Porter dan Kramer (2006) mengidentifikasi empat alasan mengapa perusahaan melakukan aktivitas CSR. Pertama, masyarakat secara umum dan perusahaan secara khusus, mempunyai keyakinan bahwa perusahaan mempunyai sebuah kewajiban moral untuk melakukan tindakan yang bermanfaat bagi banyak pihak. Kedua, konsep pembangunan berkelanjutan menekankan pentingnya perusahaan mempunyai pertanggungjawaban (stewardship) pada lingkungan dan masyarakat. Ketiga, dengan melakukan aktivitas CSR, perusahaan secara tidak langsung telah memperoleh lisensi dari masyarakat, pemerintah, dan pihak lain untuk melakukan aktivitas bisnis. Keempat, dengan bertanggung jawab secara sosial maka reputasi perusahaan dapat meningkat. Porter dan Kramer (2006) menyatakan bahwa CSR yang dilakukan perusahaan dapat memperbaiki kesan (image) perusahaan, memperkuat merk, dan bahkan memperkuat nilai sahamnya.

Perkembangan isu CSR mendorong banyaknya penelitian akuntansi yang menguji beberapa isu antara lain: (1) alasan atau determinan mengapa perusahaan melakukan CSR, (2) konsekuensi aktivitas CSR, (3) hubungan kinerja dan pengungkapan CSR, dan (4) hubungan aktivitas CSR dengan kecurangan praktek bisnis seperti manipulasi laba (Moser dan Martin, 2012). Meskipun demikian, hasil-hasil penelitian CSR terdahulu tersebut masih belum konsisten antara lain: (1) adanya berbagai competing theories yang membuat hipotesis berbeda tentang hubungan antar variabel, (2) masalah dalam disain penelitian (Paten, 2002; Clarkson et al.., 2008), dan (3) belum terpecahkannya isu penelitian bahwa aktivitas CSR dapat mengorbankan kepentingan pemegang saham.

Terdapat dua teori yang dapat digunakan untuk memprediksikan hubungan antara tingkat kinerja CSR dan tingkat pengungkapan CSR yaitu teori berbasis ekonomi dan teori berbasis sosialpolitis (Clarkson et al.., 2008). Teori berbasis ekonomi memprediksikan bahwa tingkat kinerja CSR berpengaruh positif terhadap tingkat pengungkapan CSR. Perusahaan yang mempunyai kinerja CSR yang baik mempunyai motivasi untuk menunjukkan kinerja yang baik tersebut dan tidak dapat dicapai oleh perusahaan-perusahaan lain. Tindakan ini dilakukan karena perusahaan yang mempunyai berita baik (good news) berupa kinerja CSR yang baik cenderung untuk mengungkapkannya agar masyarakat bisa membedakan perusahaan tersebut dengan perusahaan lain dengan berita buruk (bad news) berupa kinerja CSR yang kurang baik.

Perusahaan-perusahaan dengan kinerja CSR yang baik mempunyai motivasi untuk memberikan informasi tersebut kepada investor dan pemangku kepentingan lainnya. Dengan mengungkapkan informasi tentang kinerja CSR yang baik tersebut (sebagai good news), perusahaan ingin menunjukkan "kelasnya" yang berbeda dengan perusahan lain. Harapannya adalah terjadinya peningkatan nilai perusahaan di mata investor. Dengan argumentasi tersebut, teori berbasis ekonomis memprediksi bahwa semakin baik kinerja CSR maka akan semakin banyak informasi CSR yang dilaporkan. Berdasar argumen tersebut maka dapat diajukan hipotesis berikut:

H1a: Tingkat kinerja CSR berpengaruh positif terhadap tingkat pengungkapan CSR

Prediksi sebaliknya dinyatakan oleh teori berbasis sosial politis (biasa disebut juga teori legitimasi atau teori ekonomi politis). Menurut teori ini, jika perusahaan mempunyai kinerja CSR yang buruk maka hal ini dapat menyebabkan adanya tekanan sosial dan politis yang besar dan dapat mengancam legitimasinya. Untuk mengurangi tekanan tersebut maka perusahaan-perusahaan yang mempunyai kinerja yang buruk tersebut akan meningkatkan jumlah pengungkapan CSR dengan tujuan mengubah persepsi masyarakat tentang kinerja aktual CSR tersebut (Clarkson et al.., 2008). Secara terperinci, dengan mengutip Gray et al.. (1995), Clarkson et al.. (2008) menyatakan bahwa perusahaan-perusahaan yang 
terancam legitimasinya karena kinerja CSR yang buruk mempunyai motivasi untuk meningkatkan pengungkapan informasi CSR dengan tujuan: (1) menginformasikan kepada publik tentang perubahan-perubahan kinerja CSR yang telah mereka lakukan, (2) mengalihkan perhatian dari isu kinerja CSR yang buruk dengan menekankan informasi CSR dari aspek lain, dan (3) mencoba untuk mengubah persepsi dan ekspektasi publik. Paten (2002) menyatakan bahwa teori berbasis sosial politis memprediksi bahwa semakin buruk kinerja CSR maka akan semakin banyak informasi CSR yang diungkapkan.

H1b: Tingkat kinerja CSR berpengaruh negatif terhadap tingkat pengungkapan CSR

Garriga dan Mele (2004) mengklasifikasikan teori tentang CSR ke dalam empat kelompok: (1) teori etis, (2) teori politis, (3) teori integratif, dan (4) teori instrumental. Teori etis menyatakan bahwa sebuah perusahaan harus menerima CSR sebagai sebuah kewajiban etis. Teori tersebut berdasarkan prinsip seperti merupakan sebuah kewajiban untuk berkontribusi pada masyarakat dengan mengerjakan sesuatu yang benar secara etis. Dengan memfokuskan pada prinsip penggunaan kekuatan bisnis yang bertanggung jawab dalam arena politis, teori politis menekankan hubungan sebuah perusahaan dengan masyarakat dan tanggung jawab bersama pada masyarakat tersebut. Teori politis menyatakan bahwa sebuah perusahaan perlu memperhitungkan komunitas di mana perusahaan tersebut beroperasi dan berusaha mencari cara untuk memformalkan keinginan perusahaan untuk memperbaiki komunitas. Teori integratif berargumen bahwa perusahaan harus mengintegrasikan permintaan sosial ke dalam bisnis mereka karena kesuksesannya tergantung pada masyarakat. Sebaliknya, teori instrumental mempertimbangkan tujuan ekonomis sehingga CSR hanya merupakan sebuah sarana untuk menciptakan kekayaan bagi pemegang saham. Menurut teori ini, setiap aktivitas sosial hanya dapat diterima jika dan hanya jika konsisten dengan tujuan penciptaan kekayaan.

Teori etis, politis, dan integratif menyatakan bahwa perusahaan/manajer mempunyai sebuah keinginan untuk menjadi jujur, dapat dipercaya, dan etis dalam proses bisnis mereka. Beberapa studi teoritis tentang CSR mendasarkan pada pandangan etis CSR (misal Caroll 1979; Jones 1995; Philips et al.., 2003) dengan argumen bahwa terdapat sebuah dorongan moral bagi manajer untuk "do the right thing". Jones (1995) menyatakan bahwa perusahaan dengan kinerja CSR yang baik mempunyai sebuah keinginan untuk menjadi jujur, dapat dipercaya, dan etis karena perilaku tersebut bermanfaat bagi perusahaan. Oleh karena itu, jika manajer melakukan aktivitas CSR dalam konteks moralitas, maka dapat dihipotesiskan bahwa mereka tidak akan atau mengurangi tindakan manajemen laba. Manajer juga akan membuat keputusan bisnis yang bertanggung jawab sehingga menjaga transparansi dalam pelaporan keuangan. Hasil penelitian Kim et al.. (2012) memberikan bukti empiris yang mendukung hipotesis transparansi pelaporan keuangan tersebut. Mereka menunjukkan bahwa perusahaan dengan kinerja CSR yang baik cenderung mengurangi tindakan manajemen laba.

Selain pengaruh implikasi etis CSR terhadap pelaporan keuangan, terdapat dua motivasi melakukan aktivitas CSR yang berpotensi menjelaskan hubungan negatif antara tingkat kinerja CSR dan manajemen laba yaitu reputasi perusahaan. CSR dapat memberikan sebuah signal positif tentang reputasi sebuah perusahaan. Aktivitas CSR dapat dipandang sebagai sebuah sarana untuk membangun atau memelihara reputasi perusahaan. Jika perusahaan sangat memperhatikan reputasinya maka keinginan untuk menjaga reputasi tersebut dapat mencegah keinginan untuk melakukan aktivitas-aktivitas yang tidak etis seperti manipulasi laba. Manajer dapat menggunakan CSR untuk meningkatkan reputasi perusahaan dan membatasi tindakan manajemen laba untuk mengurangi risiko rusaknya reputasi mereka.

H2a: Tingkat kinerja CSR berpengaruh negatif terhadap manajemen laba.

Berbeda dengan perspektif kewajiban etis, reputasi, dan kinerja keuangan yang memprediksi hubungan negatif antara kinerja CSR dan manajemen laba, beberapa penelitian menyatakan adanya penggunaan CSR secara opportunistik sehingga tingkat kinerja CSR berpengaruh positif terhadap manajemen laba. Manajer mungkin melakukan aktivitas CSR untuk keuntungan pribadi daripada kepentingan perusahaan dan pemangku kepentingannya (Jensen dan Meckling, 1976; Caroll 1979). Berdasar perspektif biaya keagenan (agency cost), Mc Williams et al.. (2006) beragumen bahwa aktivitas CSR merupakan sebuah keuntungan manajerial (managerial perquisite) karena manajer dapat menggunakan CSR untuk meningkatkan karirnya atau agenda pribadi lainnya. Dengan menggunakan rerangka teori keagenan tentang perilaku opportunistik manajer tersebut, hasil penelitian Prior et al.. (2008) menemukan bukti empiris yang mendukung hipotesinya. 
Aktivitas CSR dapat menjadi windowdressing ketika digunakan untuk kepentingan pribadi manajer atau egoisme ekonomis organisasi. Perusahaan mungkin melakukan aktivitas CSR secara intensif untuk menutupi beberapa tindakan korporasi yang melanggar aturan. Sebagai contoh, perusahaan Enron yang melakukan manipulasi laba secara besar-besaran ternyata merupakan perusahaan dengan kinerja CSR yang tinggi. Hal tersebut menunjukkan bahwa keputusan untuk melakukan aktivitas CSR secara intensif digunakan untuk memberikan kesan transparan (transparent impression) kepada pemangku kepentingan meskipun pada kenyatannya perusahaan melakukan manajemen laba secara sembunyi-sembunyi. Kinerja CSR yang baik semata-mata dilakukan untuk menyesatkan pemangku kepentingan tentang kinerja keuangan dan nilai perusahaan. Hipotesis pelaporan keuangan opportunistik ini menyatakan bahwa perusahaan dengan kinerja CSR yang baik melakukan manajemen laba secara intensif.

H2b: Tingkat kinerja CSR berpengaruh positif terhadap manajemen laba.

Seperti halnya hipotesis hubungan antara kinerja CSR dan manajemen laba, hubungan antara tingkat pengungkapan CSR dan manajemen laba juga kemungkinan mempunyai pada arah yang berbeda. Seperti telah dinyatakan dan dibuktikan secara empiris oleh Paten dan Trompeter (2003), terdapat pengaruh positif tingkat pengungkapan CSR terhadap manajemen laba yang diproksikan dengan akrual diskresionari. Perusahaan-perusahaan dengan tingkat pengungkapan CSR yang rendah sebelum terjadinya tragedi sosial lingkungan akibat kebocoran pabrik kimia di Bhopal, India, melakukan manajemen laba secara intensif untuk menurunkan akrual diskresionari. Temuan ini sesuai dengan prediksi teori akuntansi positif khusunya political cost hypothesis (Watts dan Zimmerman, 1986) yaitu perusahaan-perusahaan yang sedang mendapatkan tekanan politis yang besar akibat aktivitas bisnisnya cenderung akan melakukan praktek manajemen laba berupa penurunan laba (income minimization).

H3a: Tingkat pengungkapan CSR berpengaruh positif terhadap manajemen laba.

Lanis dan Richardson (2012) menyatakan prediksi yang berbeda dengan hipotesis di atas dalam hubungan antara tingkat pengungkapan CSR dan praktek kecurangan bisnis (yang diproksikan dengan tingkat keagresifan pajak).
Mereka menyatakan bahwa praktek kecurangan bisnis seperti keagresifan pajak dan manajemen laba korporasi merupakan sebuah aktivitas yang tidak bertanggung jawab secara sosial dan illegitimate. Tujuan perusahaan mengungkapkan banyak informasi tentang aktivitas CSR mereka adalah membentuk profil organisasi yang baik. Oleh karena itu, mereka akan lebih berhati-hati dalam melakukan praktek kecurangan baik karena tidak konsisten dengan tujuan pembentukan profil tersebut. Selain itu, praktek kecurangan seperti manajemen laba dapat menghapus pengaruh positif dari melakukan aktivitas CSR (Lanis dan Richardson, 2012). Oleh karena itu dapat dihipotesiskan bahwa semakin tinggi tingkat pengungkapan CSR maka semakin rendah manajemen laba.

H3b: Tingkat pengungkapan CSR berpengaruh negatif terhadap manajemen laba.

Gambar 3 merupakan model penelitian ini sebagai rangkuman dari keenam hipotesis di atas.

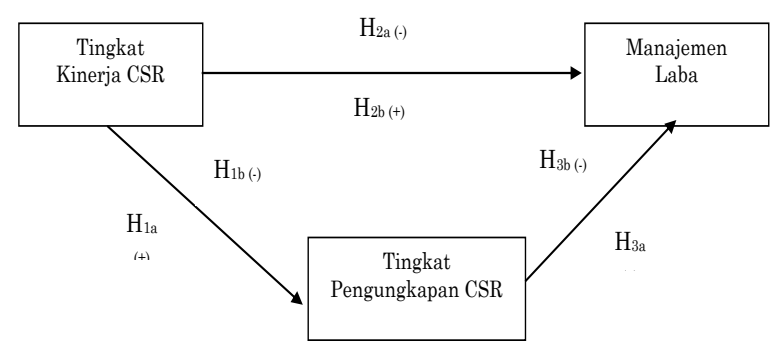

Gambar 3. Model Penelitian

\section{METODE PENELITIAN}

Populasi penelitian ini adalah seluruh perusahaan publik di Indonesia yang terdaftar di Bursa Efek Indonesia. Sampel dipilih dengan teknik purposive sampling dengan kriteria: (1) Perusahaan tersebut bukan dari industri keuangan. Perusahaan dari industri keuangan dikeluarkan dari sampel karena mempunyai karakteristik aset dan metode akuntansi yang sangat berbeda (Karampinis dan Hevas, 2011), (2) termasuk peserta PROPER, dan (3) mempunyai kelengkapan data yang dibutuhkan.

Pengukuran variabel penelitian adalah sebagai berikut:

a. Tingkat Kinerja CSR menggunakan proksi berupa peringkat kinerja PROPER yang dikeluarkan oleh Kementerian Lingkungan Hidup yang terdiri atas 7 peringkat $(7=$ emas, 6=hijau, 5=biru, 4=biru minus, 3=merah, $2=$ merah minus, dan 1=hitam). Pemberian kode tersebut menunjukkan urutan peringkat 
dengan skor 7 merupakan kinerja CSR terbaik dan skor 1 menunjukkan kinerja CSR terburuk.

b. Content analysis digunakan untuk menganalisis kuantitas dan kualitas pengungkapan CSR terhadap laporan tahunan perusahaan. Content analysis adalah metode atau teknik yang digunakan untuk mentransfer data kualitatif ke kuantitatif melalui pengkodean. Proses content analysis dilakukan dengan mengubah informasi kualitatif dari laporan tahunan menjadi skor. Hanya informasi yang relevan yang memiliki arti yang sama atau kata kunci untuk item pelaporan CSR dapat memperoleh skor. Penelitian ini mengadaptasi item pengungkapan yang digunakan oleh Hackston dan Milne (1996), Deegan et al, (2002) dan Raar (2002). Skor yang mungkin diberikan didasarkan pada karya sebelumnya yang dilakukan oleh Raar (2002) seperti dalam Tabel 1. Content analysis adalah suatu metode pengkodefikasian teks dari ciri-ciri yang sama untuk ditulis dalam berbagai kelompok (kategori) bergantung pada kriteria yang ditentukan. Selanjutnya check list dilakukan dengan melihat pengungkapan tanggung jawab sosial perusahaan yang mencakup delapan kategori, yaitu (1) Lingkungan, (2) Energi, (3) Sumber Daya Manusia, (4) Keterlibatan Masyarakat, (5) Produk, (6) Keberlanjutan, (7) Hubungan Eksternal, dan (8) Info Lainnya.

c. Variabel manajemen/manipulasi laba akan diukur dengan proksi yang dikembangkan oleh Kothari et al.. (2005).

Tabel 1. Pengukuran Kuantitas dan Kualitas Pengungkapan CSR

\begin{tabular}{|c|c|c|}
\hline $\begin{array}{c}\text { Kuantitas } \\
\text { Pengungkapan } \\
\text { "Seberapa Banyak" }\end{array}$ & $\begin{array}{c}\text { Kualitas } \\
\text { Pengungkapan } \\
\text { "Bagaimana } \\
\text { Mengukurnya" }\end{array}$ & Definisi Kualitas \\
\hline $1=$ Kalimat & $1=$ Moneter & $\begin{array}{l}\text { Diungkapkan dalam } \\
\text { moneter/satuan mata } \\
\text { uang. }\end{array}$ \\
\hline $2=$ Paragraf & $2=$ Non-Moneter & $\begin{array}{l}\text { Dalam satuan angka, } \\
\text { volume, ukuran, dll, } \\
\text { tetapi tidak dalam } \\
\text { satuan mata uang. }\end{array}$ \\
\hline $\begin{aligned} 3= & \text { Sebagian dari } \\
& \text { halaman A4 }\end{aligned}$ & 3 = Hanya Kualitatif & $\begin{array}{l}\text { Hanya dalam bentuk } \\
\text { kalimat deskriptif. }\end{array}$ \\
\hline $4=1$ halaman A4 & $\begin{array}{l}4=\text { Kualitatif dan } \\
\text { satuan mata uang }\end{array}$ & $\begin{array}{l}\text { Dalam bentuk kalimat } \\
\text { deskriptif dan satuan } \\
\text { mata uang. }\end{array}$ \\
\hline \multirow[t]{3}{*}{$5=>1$ halaman $\mathrm{A} 4$} & $\begin{array}{l}5=\text { Kualitatif dan } \\
\text { non-moneter }\end{array}$ & $\begin{array}{l}\text { Dalam bentuk kalimat } \\
\text { deskriptif dan satuan } \\
\text { angka. }\end{array}$ \\
\hline & $\begin{array}{l}6=\text { Moneter dan } \\
\text { non-moneter }\end{array}$ & $\begin{array}{l}\text { Kombinasi antara } \\
\text { satuan mata uang dan } \\
\text { angka. }\end{array}$ \\
\hline & $\begin{array}{l}7=\text { Kualitatif, } \\
\text { moneter dan non- } \\
\text { moneter }\end{array}$ & $\begin{array}{l}\text { Dalam kalimat } \\
\text { deskriptif, mata uang } \\
\text { dan angka. }\end{array}$ \\
\hline
\end{tabular}

Penelitian ini menggunakan variance-based SEM atau partial least squares (SEM-PLS) karena beberapa alasan (Hair et al.., 2011). Pertama, model penelitian ini relatif kompleks dengan lebih dari satu variabel dependen. Kedua, dalam situasi di mana teori belum berkembang (less developed), peneliti seharusnya mempertimbangkan menggunakan SEM-PLS sebagai alternatif untuk CBSEM. Hal ini terutama jika tujuan utama penelitian adalah mengaplikasikan SEM untuk memprediksi atau menjelaskan konstruk atau variabel laten yang menjadi target. Teori dalam penelitian ini masih relatif baru sehingga pengujiannya lebih tepat menggunakan SEM-PLS. Ketiga, SEM-PLS dapat bekerja secara efisien dengan ukuran sampel yang kecil dan model yang kompleks. Dalam kasus tertentu, seperti masih terbatasnya teori tentang hubungan struktural antarvariabel dan tujuan penelitian lebih pada eksploratoris daripada konfirmatoris, SEM-PLS merupakan alternatif yang tepat untuk CB-SEM. Selain itu, ketika asumsi-asumsi CB-SEM tidak terpenuhi maka SEM-PLS dapat menjadi metode yang tepat untuk pengujian teori. Berdasarkan argumentasi di atas maka penelitian ini memilih menggunakan pendekatan SEM-PLS. Penelitian ini menggunakan software WarpPLS 3.0 dalam pengujian model SEM-PLS. (Kock, 2013).

\section{HASIL PENELITIAN DAN PEMBAHASAN}

Dengan kriteria purposive sampling seperti telah diuraikan di atas maka perhitungan sampel akhir penelitian adalah seperti Tabel 2 .

Tabel 3 melaporkan distribusi frekuensi kinerja CSR seluruh amatan perusahaan. Kinerja CSR yang diproksikan dengan peringkat PROPER terdiri atas lima kategori. Sebagian besar perusahaan memperoleh peringkat biru (44,8\%) lalu diikuti peringkat hijau (30,1\%). Hanya terdapat 5 perusahaan yang memperoleh peringkat terbaik yaitu emas.

Tabel 2. Sampel Penelitian

\begin{tabular}{lc}
\hline \multicolumn{1}{c}{ Kriteria } & $\begin{array}{c}\text { Jumlah } \\
\text { Observasi }\end{array}$ \\
\hline $\begin{array}{l}\text { Perusahaan yang terdaftar di BEI dan } \\
\text { menjadi peserta PROPER 2009-2013 }\end{array}$ & 191 \\
Perusahaan dengan laporan tahunan & \\
yang tidak lengkap & $(48)$ \\
Sampel Akhir & 143 \\
\hline
\end{tabular}

Tabel 3. Distribusi Frekuensi Kinerja CSR

\begin{tabular}{clcc}
\hline & & $\begin{array}{c}\text { Jumlah } \\
\text { Perusahaan }\end{array}$ & Persentase \\
\hline \multirow{5}{*}{ Peringkat } & Hitam & 8 & 5,6 \\
& Merah & 43 & 30,1 \\
& Biru & 64 & 44,8 \\
& Hijau & 23 & 16,1 \\
& Emas & 5 & 3,5 \\
& Total & 143 & 100,0 \\
\hline
\end{tabular}


Tabel 4 menampilkan tabulasi silang kinerja CSR dan tahun amatan untuk melihat pola perkembangan kinerja CSR menurut tahun. Nampak bahwa terdapat kecenderungan penurunan peringkat perusahaan yang mendapatkan peringkat hitam dan merah. Sebaliknya terdapat kecenderungan peningkatan jumlah sampel perusahan yang mendapatkan peringkat biru dan emas. Hal ini mengindikasikan semakin meningkatnya kinerja CSR.

Gambar 4 menampilkan grafik batang yang mendukung kesimpulan sebelumnya yaitu semakin membaiknya peringkat PROPER sampel penelitian. Kinerja CSR sampel semakin meningkat ditunjukkan dengan samakin banyaknya perusahaan yang mendapat peringkat biru dan emas. Sementara terdapat penurunan jumlah perusahaan yang mendapatkan peringkat hitam dan merah.

Tabel 5 menampilkan statistik deskriptif variabel penelitian. Tingkat pengungkapan CSR dianalisis menurut kuantitas, kualitas, dan skor total gabungan keduanya. Nampak bahwa terdapat sampel perusahaan yang sama sekali tidak mengungkapkan informasi CSR ditunjukkan dengan nilai minimum kuantitas, kualitas, dan skor total sebesar 0 . Tingkat manajemen laba yang diproksikan dengan diskresionari akrual mempunyai nilai rata-rata (mean) negatif. Hal ini menunjukkan kecenderungan sampel penelitian ini menggunakan pola income decreasing dalam pilihan teknik manajemen laba.

Tabel 4. Tabulasi Silang (Cross-Tab) Tingkat Kinerja CSR

\begin{tabular}{ccccccccc}
\hline & & \multicolumn{3}{c}{ Tingkat Kinerja CSR } & Total \\
\cline { 3 - 7 } & & Hitam & Merah & Biru & Hijau & Emas & \\
\hline \multirow{4}{*}{ Tahun Amatan } & 2009 & 2 & 9 & 4 & 1 & 0 & 16 \\
& 2010 & 4 & 14 & 6 & 1 & 0 & 25 \\
& 2011 & 2 & 5 & 17 & 9 & 1 & 34 \\
& 2012 & 0 & 8 & 17 & 8 & 0 & 33 \\
\hline & 2013 & 0 & 7 & 20 & 4 & 4 & 35 \\
\hline
\end{tabular}

Tabel 5. Statistik Deskriptif Variabel Penelitian

\begin{tabular}{lrrrrr}
\hline & $N$ & Minimum & Maximum & Mean & \multicolumn{1}{c}{ Std. Deviation } \\
\hline Kuantitas Pengungkapan CSR & 143 & 0 & 123 & 45,44 & 26,453 \\
Kualitas Pengungkapan CSR & 143 & 0 & 158 & 63,10 & 34,494 \\
Skor Total Pengungkapan CSR & 143 & 0 & 273 & 108,54 & 60,166 \\
Manajemen Laba & 143 & $-0,3992$ & 0,3837 & $-0,0095$ & 0,1025 \\
\hline
\end{tabular}

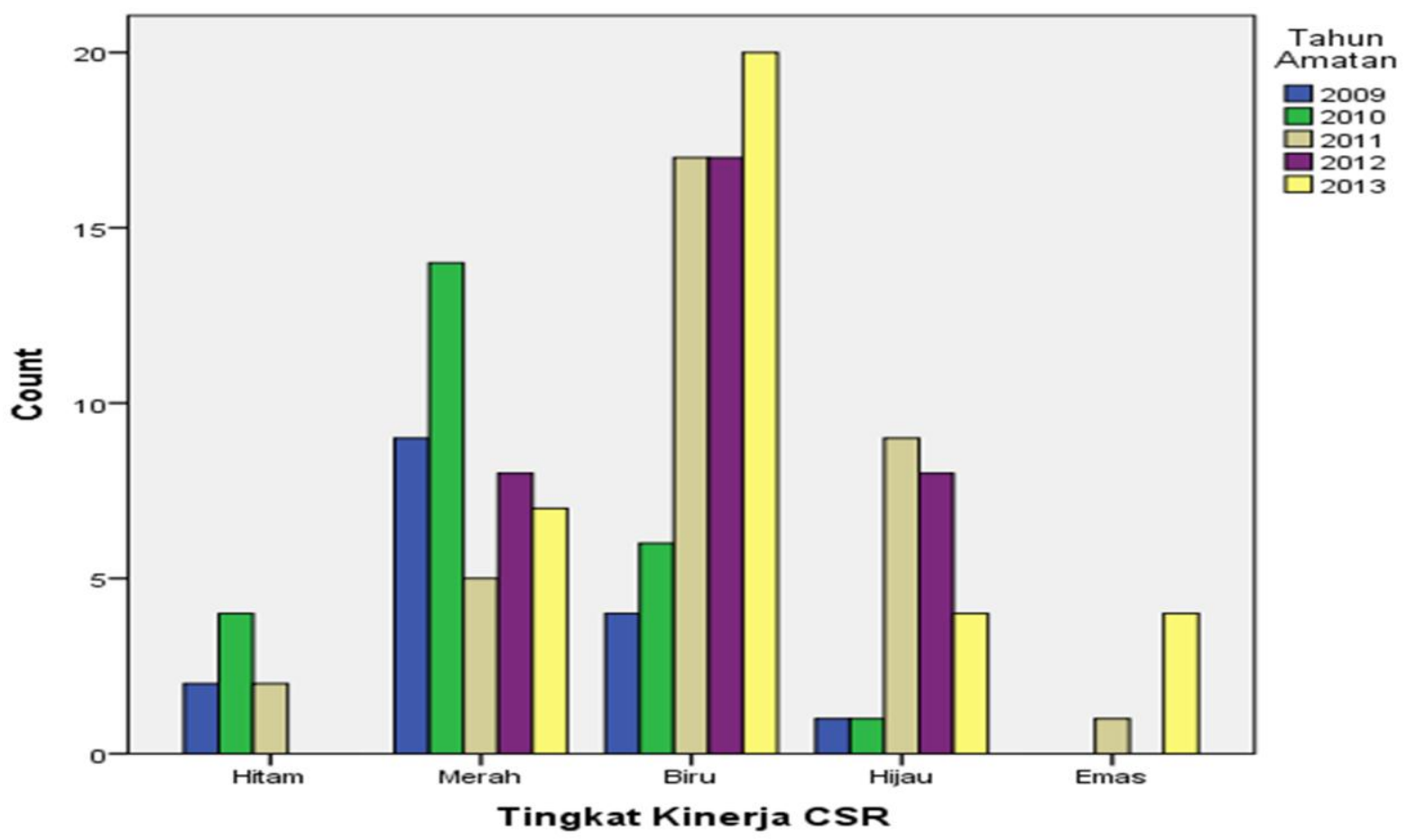

Gambar 4. Klasifikasi Peringkat Kinerja CSR Menurut Tahun 
Tabel 6 melaporkan hasil penilaian kesesuaian model menurut teori dengan data empiris (model fit indices and $P$ value). Tabel 6 menampilkan hasil tiga indikator fit yaitu average path coefficient (APC), average $R$-squared (ARS), dan average variance inflation factor $(A V I F)$. Nilai $\mathrm{p}$ diberikan untuk indikator APC dan ARS yang dihitung dengan estimasi resampling dan Bonferroni like corrections. Hal ini diperlukan karena keduanya dihitung sebagai rata-rata parameter. Evaluasi apakah model fit (sesuai atau didukung) oleh data adalah sebagai berikut. Nilai $p$ untuk APC dan ARS harus lebih kecil dari 0,05 atau berarti signifikan. Selain itu, AVIF sebagai indikator multikolinearitas harus lebih kecil dari 5 . Hasil output menunjukkan kriteria goodness of fit model telah terpenuhi untuk APC yaitu sebesar 0,198 dan ARS sebesar 0,102 serta bernilai signifikan dengan nilai $p$ kurang dari 0,05 . Nilai AVIF sebesar 1,225 juga telah memenuhi kriteria yaitu di bawah batasan 5. Secara keseluruhan, hasil model fit menunjukkan bukti model menurut teori didukung oleh data.

\section{Tabel 6. Indeks Goodness of Fit Model}

\begin{tabular}{ll}
\hline Model fir indices and $\mathrm{P}$ values \\
\hline & \\
$\mathrm{APC}=0.198$, & $\mathrm{P}<0.001$ \\
$\mathrm{ARS}=0.102$, & $\mathrm{P}=0.002$ \\
$\mathrm{AVIP}=1.225$, & Good if $<5$ \\
\hline
\end{tabular}

Gambar 5 menunjukkan hasil pengujian hipotesis hubungan antarvariabel (model struktural). Hasil pengujian menunjukkan variabel kinerja CSR (Kin_CSR) berpengaruh positif terhadap pengungkapan CSR (Peng_CSR) dengan koefisien regresi sebesar 0,43 dan signifikan dengan nilai $\mathrm{p}$ kurang dari 0,01 . Hasil ini menunjukkan dukungan terhadap hipotesis 1a. Tingkat kinerja CSR tidak berpengaruh terhadap manajemen laba dengan koefisien regresi sebesar 0,05 dan nilai $\mathrm{p}$ sebesar 0,29. Tingkat pengungkapan CSR cenderung berpengaruh negatif terhadap manajemen laba dengan koefisien regresi $-0,12$ dan signifikan dengan nilai $p$ kurang dari $10 \%$. Hasil ini menunjukkan dukungan terhadap hipotesis 3b. Secara keseluruhan, hasil pengujian menunjukkan dukungan terhadap H1a dan H3b.

Untuk memperoleh hasil penelitian yang robust maka dilakukan beberapa analisis tambahan. Pertama, model dengan tingkat pengungkapan CSR diukur dengan kuantitas pengungkapan CSR. Hasil pengujian pada gambar 6 menunjukkan dukungan hanya terhadap H1a yaitu tingkat kinerja CSR berpengaruh positif terhadap tingkat pengungkapan CSR.

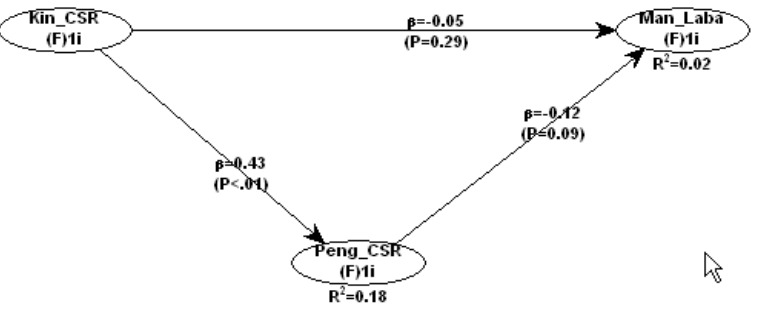

Gambar 5. Hasil Pengujian Model Dasar

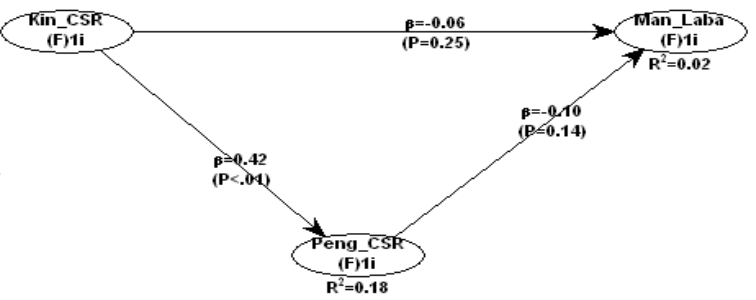

Gambar 6. Hasil Pengujian Model Kuantitas Pengungkapan CSR

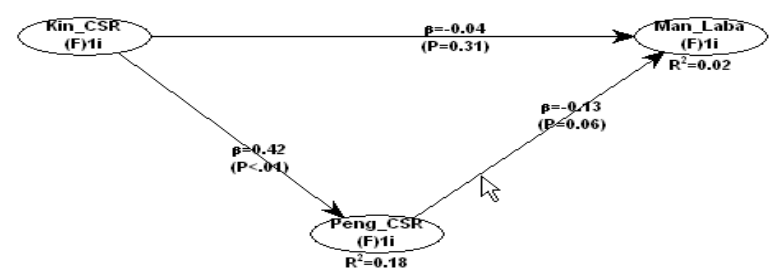

Gambar 7. Hasil Pengujian Model Kualitas Pengungkapan CSR

Analisis tambahan selanjutnya dengan pengungkapan CSR diukur dengan kualitas pengungkapan CSR. Hasil pengujian pada gambar 7 menunjukkan dukungan terhadap H1a (kinerja CSR berpengaruh positif terhadap pengungkapan CSR) dan H3b (pengungkapan CSR berpengaruh negatif terhadap manajemen laba).

Analisis tambahan selanjutnya dilakukan dengan melakukan estimasi model untuk setiap tahun. Secara ringkas hasilnya adalah sebagai berikut. Hasil pengujian untuk model tahun 2009 menunjukkan dukungan temuan sebelumnya yaitu dukungan terhadap H1a (kinerja CSR berpengaruh positif terhadap pengungkapan CSR) dan H3b (pengungkapan CSR berpengaruh negatif terhadap manajemen laba). Hasil pengujian untuk model tahun 2010 hanya menunjukkan dukungan terhadap H1a yaitu tingkat kinerja CSR berpengaruh positif terhadap tingkat pengungkapan CSR. Hasil pengujian untuk model tahun 2011 juga hanya menunjukkan dukungan terhadap H1a yaitu kinerja CSR berpengaruh positif terhadap pengungkapan CSR. Hasil pengujian model tahun 2012 menunjukkan dukungan terhadap H1a (kinerja CSR berpengaruh positif terhadap pengungkapan CSR) dan H3b (pengungkapan CSR berpengaruh negatif terhadap manajemen 
laba).Hasil pengujian untuk model tahun 2013 hanya menunjukkan dukungan terhadap H1a yaitu kinerja CSR berpengaruh positif terhadap pengungkapan CSR.

Secara keseluruhan, hasil pengujian menunjukkan bukti yang konsisten untuk dukungan terhadap hipotesis 1a yaitu tingkat kinerja CSR berpengaruh positif terhadap pengungkapan CSR. Selain itu, terdapat kecenderungan sebagian besar hasil pengujian menunjukkan dukungan terhadap H3b yaitu tingkat pengungkapan CSR berpengaruh negatif terhadap manajemen laba.

Hasil pengujian menunjukkan temuan yang konsisten bahwa kinerja CSR berpengaruh positif terhadap kinerja CSR. Hasil ini menunjukkan dukungan teori berbasis ekonomi. Teori berbasis ekonomi, khususnya teori pensignalan (signaling theory) memprediksi bahwa tingkat kinerja CSR berpengaruh positif terhadap tingkat pengungkapan CSR. Perusahaan yang mempunyai kinerja CSR yang baik mempunyai motivasi untuk menunjukkan kinerja yang baik tersebut dan tidak dapat dicapai oleh perusahaan-perusahaan lain. Tindakan ini dilakukan karena perusahaan yang mempunyai berita baik (good news) (kinerja CSR yang baik) cenderung untuk mengungkapkannya agar masyarakat bisa membedakan perusahaan tersebut dengan perusahaan lain dengan berita buruk (bad news) (kinerja CSR yang kurang baik).

Perusahaan-perusahaan dengan kinerja CSR yang baik mempunyai motivasi untuk memberikan informasi tersebut kepada investor dan pemangku kepentingan lainnya. Dengan mengungkapkan informasi tentang kinerja TJSL yang baik tersebut (sebagai good news), perusahaan ingin menunjukkan "kelasnya" yang berbeda dengan perusahan lain. Harapannya adalah terjadinya peningkatan nilai perusahaan di mata investor. Dengan argumentasi tersebut, teori berbasis ekonomis memprediksi bahwa semakin baik kinerja CSR maka akan semakin banyak informasi CSR yang dilaporkan.

Hasil penelitian ini juga menunjukkan dukungan terhadap H3b yaitu tingkat pengungkapan CSR berpengaruh negatif terhadap manajemen laba. Hasil ini sesuai argument Lanis dan Richardson (2012) yang menyatakan bahwa praktek kecurangan bisnis seperti keagresifan pajak dan manajemen laba korporasi merupakan sebuah aktivitas yang tidak bertanggung jawab secara sosial dan illegitimate. Tujuan perusahaan mengungkapkan banyak informasi tentang aktivitas CSR mereka adalah membentuk profil organisasi yang baik. Oleh karena itu, mereka akan lebih berhati-hati dalam melakukan praktek kecurangan baik karena tidak konsisten dengan tujuan pembentukan profil tersebut. Selain itu, praktek kecurangan seperti manajemen laba dapat menghapus pengaruh positif dari melakukan aktivitas CSR (Lanis dan Richardson, 2012). Oleh karena itu, semakin tinggi tingkat pengungkapan CSR maka semakin rendah manajemen laba. Secara ringkas, temuan di atas dapat digambarkan dalam model empiris pada Gambar 8.

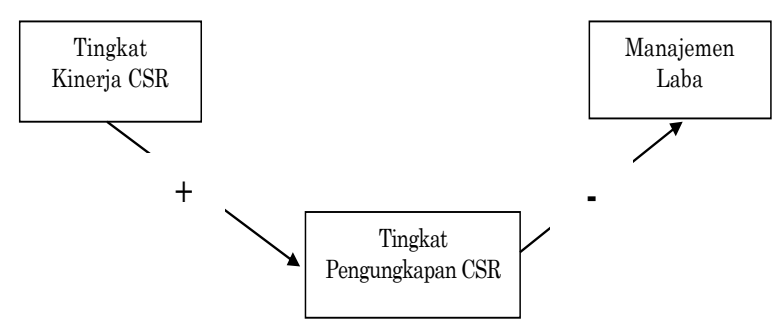

Gambar 7. Model Empiris

\section{KESIMPULAN DAN SARAN}

Penelitian ini bertujuan menguji hubungan antara tingkat kinerja CSR, tingkat pengungkapan CSR, dan manajemen laba. Penelitian ini penting dilakukan karena terdapat dua teori yang bertentangan (competing theories) yang memberikan prediksi yang berbeda tentang arah hubungan antara tingkat pelaporan CSR, tingkat kinerja CSR, dan manajemen laba. Dua teori yang bertentangan tersebut adalah teori berbasis ekonomis (economic-based theory) dan teori berbasis sosialpolitis (socio-political theory). Hasil penelitian ini menunjukkan dukungan terhadap teori berbasis ekonomi khususnya teori signaling karena terdapat bukti empiris yang konsisten bahwa tingkat kinerja CSR berpengaruh positif terhadap tingkat pengungkapan CSR. Hasil penelitian juga menunjukkan tingkat pengungkapan CSR cenderung berpengaruh negatif terhadap manajemen laba. Temuan ini mendukung argumen Lanis dan Richardson (2012) yang menyatakan bahwa tujuan perusahaan mengungkapkan banyak informasi tentang aktivitas CSR mereka adalah membentuk profil organisasi yang baik. Oleh karena itu, mereka akan lebih berhati-hati dalam melakukan praktik manipulasi laba karena tidak konsisten dengan tujuan pembentukan profil tersebut. Selain itu, praktek kecurangan seperti manajemen laba dapat menghapus pengaruh positif dari melakukan aktivitas CSR (Lanis dan Richardson, 2012).

Berdasar hasil studi empiris penelitian ini maka dapat disusun beberapa saran bagi perusahaan, investor, dan penelitian mendatang. Sesuai dengan teori signaling, terdapat kecenderungan perusahaan yang mempunyai kinerja CSR yang baik akan mengungkapkannya ke publik melalui laporan tahunan. Hal ini penting karena merupakan impression management 
dengan CSR cenderung digunakan strategi perusahaan. Investor masih perlu memverifikasi lebih lanjut tingkat manajemen laba perusahaanperusahaan yang mempunyai kinerja dan pengungkapan CSR yang tinggi.

Terdapat beberapa keterbatasan penelitian ini. Pertama, pengukuran variabel kinerja CSR terbatas validitas konstruknya pada hasil penilaian program PROPER Kementerian Lingkungan Hidup. Data PROPER merupakan satu-satunya yang tersedia untuk mengukur kinerja CSR terutama aspek lingkungan. Kedua, pengukuran pengungkapan CSR juga terbatas pada informasi yang tersedia pada laporan tahunan. Hal ini karena terbatasnya perusahaan yang mempublikasikan sustainability reporting sebagai media pengungkapan CSR sehingga jika digunakan akan tidak memenuhi persyaratan pengujian statistis. Validitas internal penelitian ini juga terbatas untuk dapat memastikan hubungan kausalitas. Dalam rangka meningkatkan validitas internal, penelitian mendatang dapat menggunakan setting eksperimen laboratorium. Penelitian mendatang juga dapat menggunakan proksi manajemen laba selain akrual seperti manipulasi aktivitas riil. Penelitian ini tidak menggunakan proksi tersebut karena adanya kemungkinan subtitusi sehingga perusahaan tidak menggunakan teknik akrual dan manipulasi aktivitas riil secara bersama-sama (Kim, 2012).

\section{DAFTAR PUSTAKA}

Anggraeni, Fr. (2006). Corporate Social Disclosure and Its Influencing Factors. Makalah The $9^{\text {th }}$ Indonesian National Symphosium in Accounting.

Cahyonowati, N. (2010). Pelaporan dan Kinerja Pertanggungjawaban Lingkungan Perusahaan-perusahaan Publik di Indonesia. Laporan Penelitian DIPA FEB Undip.

Cahyonowati, N. (2011). Kompensasi Manajemen dan Manajemen Laba: Pengujian Bonus Plan Hypothesis dalam konteks Indonesia. Laporan Penelitian DIPA FEB Undip.

Cahyonowati, N. (2012). Adopsi IFRS dan Kualitas Informasi Akuntansi: Sebuah Studi Eksploratori. Laporan Penelitian DIPA FEB Undip

Carroll, A. (1979). A three-dimensional conceptual model of corporate performance. The Academy of Management Review, 4(4), 497-505.

Chih, H., Shen, C., \& Kang, F. (2008). Corporate social responsibility, investor protecttion, and earnings management: Some international evidence. Journal of Business Ethics, 79(1/2), 179-198.
Clarkson, P. M., Li, Y., \& Richardson, G. (2008). Revisiting the relation between environmenttal performance and environmental disclosure: An empirical analysis. Accounting, Organisations and Society, 33, 303-327.

Garriga, E. \& Mele', D. (2004). Corporate social responsibility theories: Mapping the territory. Journal of Business Ethics, 53(1/2), 51-71.

Gray, R., Kouhy, R., \& Lavers, S. (1995). Corporate social and environmental reporting: a review of the literature and a longitudinal study of UK disclosure. Accounting. Auditing \& Accountability Journal, 8(2), 47-77.

Hong, Y. \& Andersen, M. (2011). The Relationship Between Corporate Social Responsibility and Earnings Management: An Exploratory Study. Journal of Business Ethics, 104, 461-471.

Jensen, M. \& Meckling, W. (1976). Theory of the firm: Managerial behavior, agency costs and ownership structure. Journal of Financial Economics, 3, 305-360.

Kementrian Negara Lingkungan Hidup. (2012). Laporan hasil penilaian PROPER periode 2011-2012.

Kim, Y., Park, M. S., \& Wier, B. (2012). Is earnings quality associated with corporate social responsibility? The Accounting Review, 87(3), 761-796.

Leuz, C., Nanda, D., \& Wysocki, P. (2003). Earnings management and investors protection: An international comparison. Journal of Financial Economics, 69(3), 505-527.

Moser, D. \& Martin, P. (2012). A Broader Perspective on Corporate Social Responsibility Research in Accounting. The Accounting Review, 87(3), 797-806.

Patten, D.M. (2002). The relation between environmental performance and environmental disclosure: a research note. Accounting, Organizations and Society, 27(8), 763-773.

Patten, D. \& Trompeter, C. (2003). Corporate responses to political costs: an examination of the relation between environmental disclosure and earnings management. Journal of Accounting and Public Policy, 22, 83-94.

Porter, M. E. \& Kramer, M. R. (2006). The link between competitive advantage and corporate social responsibility. Harvard Business Review, 84(12), 78-92.

Prior, D., Surroca, J., \& Tribo, J. (2008). Are socially responsible managers really ethical? Exploring the relationship between earnings management and corporate social responsibility. Corporate Governance, 16(3), 160-177.

Suratno, Bondan Ignatius. (2006). The Effect Environmental Performance on Environmental Disclosure and Economic Performance. Thesis on Magister of Accounting of Diponegoro Unversity. Unpublished. 